\title{
Too Good to be True: Board Structural Independence as a Moderator of CEO Pay-for-Firm-Performance
}

\section{Alessandra Capezio, John Shields and Michael O'Donnell}

Australian National University; University of Sydney; University of New South Wales

\begin{abstract}
Whether voluntary or mandatory in nature, most recent corporate governance codes of best practice assume that board structural independence, and the application by boards of outcome-based incentive plans, are important boundary conditions for the enforcement of Chief Executive Officer (CEO) pay-for-firm-performance; that is, for optimal contracting between owners and executive agents. We test this logic on a large Australian sample using a system Generalized Method of Moments (GMM) approach to dynamic panel data estimation. We find that Australian boards exhibiting best practice structural arrangements - those chaired by non-executives and dominated by non-executive directors at the full board and compensation committee levels - are no more adept at enforcing CEO pay-for-firm-performance than are executive-dominated boards. These findings suggest that policy makers' faith in incentive plans and the moderating influence of structural independence per se may be misplaced. Our findings also hold significant implications for corporate governance theory. Specifically, the findings lend further support to a contingency-based understanding of board composition, reward choice and monitoring; an approach integrating the insights afforded by behavioural approaches to Agency Theory and by social-cognitive and institutional understandings of director outlook, decision-making and behaviour.
\end{abstract}

\section{INTRODUGTION}

The requirement that company directors should be materially 'independent' from the firm's hired managers is one of the hallmarks of contemporary corporate governance codes of best practice (e.g. Australian Stock Exchange Corporate Governance Council, 2003). Independent boards, independent chairpersons, and independent compensation committees are seen as being essential for good governance in general and, in particular, for optimal contacting between owners and executives. Independence, it is assumed, facilitates board diligence and arms-length rationality across the director task range, particularly the management of Chief Executive Officer (CEO) performance and reward. Further, while independence from incumbent executives can be construed in

Address for reprints: Alessandra Capezio, School of Management, Marketing and International Business, Australian National University, Canberra, ACT 0200, Australia (alessandra.capezio@anu.edu.au). 
terms that are either broad (e.g. no common social or economic interests of any type) or narrow (e.g. no overlapping membership of other boards), it is the non-executive outsider who is typically perceived as being the archetype of director independence. Such prescriptions are redolent of the Managerial Power model of governance theory (Bebchuk and Fried, 2004; Gumbel, 2006) which posits director independence from incumbent executives as a critical safeguard against managerial dominance and 'board capture'.

Further, best practice codes typically prescribe outcome-based incentives - that is, incentives linked objectively to either firm operating returns, market returns, or both - as the optimal means by which boards can align the material interests of owners and executives. This view accords with the traditional Agency Theory conception of the firm, which has been pivotal in casting CEO pay-for-firm-level-performance as a key signifier of the board's commitment to aligning the interests of the CEO and shareholders (Abowd, 1990; Fama and Jensen, 1983; Grabke-Rundell and Gomez-Mejia, 2002; Jensen and Murphy, 1990; Levinthal, 1988). Where CEO pay is instrumentally sensitive to firm operational and/or market performance, ex post, boards are inferred to have created incentive alignment, and demonstrated diligent supervision (Tosi and GomezMejia, 1989).

However, empirical support for each of these best practice prescriptions remains inconclusive. While Agency Theory predicts a strong association between executive pay and firm performance in situations where boards do apply outcome-based incentive contracts, the research results from various countries suggest that the pay-forperformance association is either non-existent or, at best, weakly positive (Tosi et al., 2000). Further, while the Managerial Power model predicts that directors who are independent/non-executive/outsiders will be more adept at optimal contracting and incentive alignment, the evidence that this is so is ambiguous. A number of studies have found that having outsiders or insiders makes no difference to the association between CEO pay and performance, or does very little to explain the variation in CEO pay levels and structures (Conyon, 2006; Conyon and Peck, 1998; Dalton and Daily, 1994; Kerr and Kren, 1992; Murphy, 2002; O’Reilly and Main, 2007).

A growing body of research questions whether the combination of board independence and outcome-based incentives is necessarily the best combination in all cases and all contexts. For example, researchers have shown that in contexts where there is a high level of extraneous market 'noise' and volatility in firm-level performance, the association between CEO pay and firm performance is generally weaker precisely in order to account for CEO risk-bearing (Aggarwal and Samwick, 1999; Conyon and Sadler, 2001; Lambert and Larcker, 1987; Miller et al., 2002; Mishra et al., 2000). Further, studies informed by behavioural versions of Agency Theory have found that in some contexts boards may prefer 'subjective' behaviour-based assessment and contracting rather than 'objective' outcome-based contracts (Eisenhardt, 1989; Larraza-Kintana et al., 2007; Wiseman and Gomez-Mejia, 1998). More particularly, there is some evidence that the choice between behaviour-based contracts and outcome-based contracts may depend partly on whether the board consists chiefly of inside or outside appointees (CaranikasWalker et al., 2007). As such, it may be that the association between board independence, ex ante outcome-based incentive use, and ex post pay-for-performance-sensitivity is contingent rather than certain. 
Thus, is remains unclear whether, and under what circumstances, board structural characteristics assumed to be conducive to director independence and incentive alignment do moderate the association between CEO pay and firm-level outcomes.

This study makes several important conceptual and empirical contributions to the corporate governance, executive performance, and reward management literatures. Firstly, it presents evidence which contradicts the Managerial Power axiom that board structural independence is a necessary condition for high pay-for-performance sensitivity. Secondly, it furnishes evidence supportive of the behavioural Agency Theory perspective that questions whether board structural independence necessarily buttresses the board's willingness and ability to enforce CEO pay-for-firm-level-performance. Thirdly, by using a system Generalized Method of Moments (GMM) approach to parameter estimation, an approach that is particularly appropriate for dynamic panel models, the study addresses several major shortcomings associated with more common methods for estimating pay-for-performance sensitivity.

Overall, our results challenge both the structural determinism of the Managerial Power approach and the incentive instrumentalism of traditional Agency Theory. Further, our findings highlight the need for an integrative and multi-theoretic approach to understanding the board's orientation to and influence over CEO pay-forperformance. Such an approach, we contend, should underscore the primacy of cognitive and social factors - as opposed to structural factors - in shaping the board's role in the determination of $\mathrm{CEO}$ compensation.

\section{BOARD GOMPOSITION, BOARD MONITORING, AND GEO PAY}

From a traditional Agency Theory perspective, board composition per se is held to be largely unproblematic, with the principal-agent problem and its solution being viewed in instrumental economic terms. Boards, as diligent and trustworthy stewards of collective shareholder interest, remedy the information asymmetry between distal owners and self-serving, risk-averse agents by choosing and applying appropriate means of monitoring, evaluating, and rewarding executive performance. In the reward determination process, the board is seen as making rational trade-offs between the cost of obtaining necessary information on executive performance (i.e. 'agency costs') and the anticipated benefit in the form of maximum alignment between executive and shareholder material interests. From the traditional Agency Theory perspective, the most cost-effective means of achieving 'optimal contracting' along these lines are posited to be outcome-based incentive plans geared to 'objective' firm-level operational and/or market performance criteria (Eisenhardt, 1989; Fama, 1980; Jensen and Meckling, 1976; Jensen and Murphy, 1990).

In contrast, Managerial Power Theory contends that board structural arrangements are important boundary conditions for board monitoring and for aligning CEO pay to firm performance. Boards dominated by executive insiders are assumed to be problematic monitors and compromised compensation decision-makers, given that the CEO can influence fellow executives' rewards and career advancement (Beatty and Zajac, 1994). Further, Managerial Power Theory proposes that CEOs who are also board chairpersons have the power to influence board decisions in general, but especially the setting of 
CEO pay (Boyd, 1994; Finkelstein and Hambrick, 1988). Combining the role of board chairperson and CEO (i.e. chair-CEO 'duality') is said to render directors beholden to the $\mathrm{CEO}$ and, hence, to create the conditions for board complicity or 'capture' (Bebchuk and Fried, 2004; Cadbury, 2002; Gumbel, 2006; Huse, 2007). Separating these roles has been proffered as a means of increasing the board's capacity to monitor the CEO and advance the interests of shareholders (Cadbury, 2002). Having an outsider as board chair serves as an 'additional monitor of managerial behavior' (Beatty and Zajac, 1994, p. 319). From this perspective, having a CEO as chairperson and a preponderance of executive directors, as well as an executive-dominated compensation committee, are ways that the $\mathrm{CEO}$, in an effort to hedge compensation risk, can dilute board monitoring and decouple $\mathrm{CEO}$ pay from performance.

These Managerial Power Theory propositions are not without empirical support. Beatty and Zajac (1994) found that in firms where managers had higher levels of performance-based pay relative to total pay, there was a higher proportion of outside directors, as well as a separation of CEO and chairperson positions. Subsequent studies have provided further support for these findings (Boyd, 1994; Core et al., 1999; Finkelstein and Hambrick, 1989). Likewise, there is some evidence that non-executive dominated boards are more adept at constraining executive misbehaviour. For instance, Fong (2010) reports that in situations where CEOs are underpaid relative to the market, the likelihood of a negative behavioural response by the CEO (such as failing to invest in research and development innovation) is reduced where the firm is 'owner-controlled' rather than 'manager-controlled'. Therefore, there is some evidence that board structural independence may provide the necessary conditions for incentive alignment.

There is, however, a considerable body of argument and evidence against best practice prescriptions for board independence and outcome-based contracting. Some researchers question whether outside unaffiliated directors necessarily make more effective monitors. Mirroring the structural determinist logic evident in the Managerial Power perspective, some studies suggest that executive insiders may be more effective in appraising and rewarding $\mathrm{CEO}$ performance, and thus in securing incentive alignment, because they possess greater knowledge of the firm's operational and financial management (Baysinger and Hoskisson, 1990; Donaldson and Davis, 1991; Finkelstein and D'Aveni, 1994; Pfeffer, 1972). Several studies suggest that having boards dominated by executive directors may actually constrain CEO pay and increase contractual efficiency (Core et al., 1999; Deutsch, 2005).

A further possibility is that board composition may impinge on pay sensitivity indirectly by influencing the design of CEO reward contracts per se and, in turn, ex post CEO reward levels. According to traditional Agency Theory, boards that utilize incentives based on firm-level outcomes are ipso facto more effective at aligning the interests of risk- and effort-averse CEOs to those of shareholders. However, there is some conceptual and empirical disagreement - both between agency theorists and others, and between agency theorists themselves - as to whether contracts based on firm-level outcomes are necessarily optimal, effective, or even appropriate in all contexts (Baysinger and Hoskisson, 1990; Beatty and Zajac, 1994; Eisenhardt, 1989; Hall and Liebman, 1998). 
The chief areas of doubt about outcome-based incentive plan effectiveness and appropriateness are threefold. Firstly, given their presumed risk aversion, CEOs may seek ways to hedge the compensation risk stemming from highly outcome-contingent pay. For example, extant research evidence, particularly that informed by Managerial Power Theory, shows that CEOs can manipulate the terms and conditions of outcome-based incentive plans in ways that decouple their compensation from firm performance (Bebchuk and Fried, 2004; Bettis et al., 2005; Burns and Kedia, 2006; Cho and Hambrick, 2006; Devers et al., 2007; Knopf et al., 2002). For instance, where incentives are based on short-term operational criteria, such as annual net operating profit, expenditure levels may be manipulated to artificially inflate net returns. Likewise, where incentives are geared to market returns, information released to the market may be manipulated so as to artificially inflate or deflate the company's share price (Aboody and Kasznik, 2000). In short, contrary to the traditional Agency Theory premise, the ex ante adoption of outcome-based contracting does not guarantee ex post optimality. Further, according to the Managerial Power schema, the probability of board capture, contract sub-optimality, and performance pay decoupling is greater where the board is dominated by executive insiders.

Secondly, within the traditional Agency Theory domain itself, there is substantial evidence that in situations of high firm-level risk, optimal contracting may require less rather than more emphasis on outcome-based incentives and, conversely, more rather than less emphasis on the evaluation and reward of CEO behaviour. Extraneous noise in a firm's share price performance can increase the CEO's risk bearing such that a risk compensation premium is required to offset the agent's risk aversion (GomezMejia and Wiseman, 1997). Some researchers (Aggarwal and Samwick, 1999; Merhebi et al., 2006; Mishra et al., 2000) have investigated the moderating effects of the variance or 'riskiness' of firm real stock returns on the CEO pay-for-performance relationship on the premise (consistent with traditional Agency Theory) that CEO risk preferences negatively moderate the association between CEO pay and firm performance. In support of this proposition, these researchers have found that CEO payfor-firm-performance sensitivity falls as firm-specific risk increases (Aggarwal and Samwick, 1999; Conyon and Sadler, 2001; Lambert and Larcker, 1987; Miller et al., 2002; Mishra et al., 2000). Thus, on the basis of traditional Agency Theory assumptions, outcome-based incentives may be inappropriate in situations of high firm-specific risk.

Thirdly, it has been suggested by exponents of the behavioural variant of Agency Theory that in some circumstances boards may prefer instituting behaviour-based rather than outcome-based incentive schemes to achieve alignment and optimal contracting (Eisenhardt, 1989; Larraza-Kintana et al., 2007; Wiseman and Gomez-Mejia, 1998). Behavioural Agency Theory proposes that the traditional Agency Theory advocacy of incentives based on firm-level outcomes runs the twin risks of oversimplifying the board's management of incentive alignment and giving rise to perverse consequences (Tosi and Gomez-Mejia, 1989; Wiseman and Gomez-Mejia, 1998). Behavioural Agency Theory proposes that incentive alignment can be achieved through either outcome-based contracts, behaviour-based contracts, or a combination of the two (Eisenhardt, 1989; Larraza-Kintana et al., 2007; Wiseman and Gomez-Mejia, 1998). While outcome-based 
contracts link CEO pay to firm-level performance, behaviour-based contracts link pay to the board's direct supervision of CEO behaviour, decisions, and actions, which, in turn, are assumed to have a positive, if indirect, influence on firm performance (Wiseman and Gomez-Mejia, 1998). Following on from this it is suggested that in some circumstances the use of behaviour-based contracts may be the more appropriate alignment mechanism (Eisenhardt, 1989).

Some exponents of behavioural Agency Theory also posit a direct link between board composition and the choice between outcome-based and behaviour-based contracting. Boards dominated by outsiders may opt for outcome-based contracting more as a matter of necessity than because outsiders are necessarily more diligent in pursuing incentive alignment (Wiseman and Gomez-Mejia, 1998). Baysinger and Hoskisson (1990) suggest that board composition influences the mechanisms of control used by the board to ameliorate agency problems. More specifically, boards dominated by outside directors are believed to be at a comparative disadvantage. Being unable to monitor or evaluate CEO behaviour and strategy implementation on a direct and continuous basis, they find it difficult, if not untenable, to apply behaviour-based incentive contracts (Baysinger and Hoskisson, 1990; Caranikas-Walker et al., 2007). In this sense, inside directors are seen as being less vulnerable to information asymmetry than outsiders. Direct monitoring of CEO behaviour and the use of pay-for-individualbehaviour may be untenable for outside directors because it requires them to make informed judgments concerning complex firm-specific executive tasks about which they may have only limited information; information that, in any case, is likely to be filtered by executives themselves. In other words, the use of behavioural criteria by outsiderdominated boards is likely to be confounded by information asymmetry (Sundaramurthy and Lewis, 2003; Wiseman and Gomez-Mejia, 1998). Except perhaps in situations of very high firm risk, such boards are thus more likely to fall back on outcome-based schemes precisely because they are unable to monitor CEO behaviour directly and reliably (Caranikas-Walker et al., 2007).

These propositions also have some support in the extant research. For instance, Makri et al. (2006) found that while firm-level performance measures were linked to annual incentive cash payments, CEO total pay was linked to behavioural criteria. These researchers suggest that firm-level performance measures may be more informative signals of CEO efforts for directors who lack sufficient information to make an informed judgment about behavioural criteria (Makri et al., 2006). Similarly, Caranikas-Walker et al. (2007) found that while it is common for boards to use a mix of outcome and behavioural criteria, insider-dominated boards were more likely to prefer behaviourbased short-term bonuses, particularly in situations of high firm-level risk and outcome uncertainty, such as high research and development intensity.

Overall, then, the behavioural Agency Theory perspective suggests that boards dominated by outside/non-executive directors will be inclined to apply a second best approach to GEO monitoring and reward - that of incentive plans geared to share market outcomes. This, of course, runs directly counter to traditional Agency Theory's faith in such plans. Further, while redolent of Managerial Power's emphasis on the vulnerability of outcome-based incentives to managerial manipulation, it also contradicts Managerial Power's faith in the superiority of outsider-dominated boards. 


\section{Hypotheses}

As we have seen, the three main theoretical points of departure in this domain - namely traditional Agency Theory, the Managerial Power perspective, and behavioural Agency Theory - have both convergent and divergent characteristics. Traditional Agency Theory prescribes outcome-based incentives while viewing board composition as unproblematic. Managerial Power focuses on how board composition (i.e. degree of independence) can either encourage or counteract CEO manipulation of outcome-based incentives. Behavioural Agency Theory also acknowledges the vulnerability of outcomebased contracting but is concerned chiefly with how board composition influences the criteria used by board members to evaluate and reward CEO performance.

So the question remains: Is director independence (proxied by outside non-executive status) more conducive to alignment between CEO pay and firm-level outcomes (proxied by operating and market returns), or less so? A related consideration, though one that has hitherto attracted limited research attention, is the governance level at which independence might be most influential. If director independence does increase CEO pay-for-performance sensitivity, is this more likely to be the case at full board level, at chair level, or at remuneration committee level? In this study, we test the influence of independence at each of these governance levels.

Non-executive-dominated boards. Drawing on the central tenet of Managerial Power Theory, we hypothesize that:

Hypothesis 1: The proportion of non-executive directors on the board moderates the association between CEO pay and firm performance in such a way that the association is stronger where the proportion of non-executive directors is higher.

Non-executive chairpersons. Few studies have examined the influence of having a nonexecutive chairperson on the relationship between CEO pay and firm performance, even though the separation of CEO and chairperson roles is suggested to enhance board independence and diligence, and to thwart CEO entrenchment. Consistent with the Managerial Power perspective, independence at the board chair level has emerged as one of the most prominent signifiers of 'good governance', even though descriptive research suggests that $\mathrm{CEO}$-chair duality remains common practice in countries like the USA and UK (Reilly and Scott, 2005). We therefore hypothesize that:

Hypothesis 2: Having a non-executive chairperson moderates the association between CEO pay and firm performance in such a way that the association is stronger when there is a non-executive chairperson than when there is not.

Non-executive dominated compensation committees. The standard model of corporate governance now favoured in Australia, the USA, and the UK prescribes board committees consisting of a majority of independent directors (Australian Stock Exchange Corporate Governance Council, 2003; Cadbury, 2002). However, this prescription remains more 
an article of regulatory faith than an empirically-validated truth. Few studies have examined the influence of having a non-executive-director-dominated compensation committee on CEO pay-for-performance, even though such committees are charged with the responsibility for formulating proposals for managing $\mathrm{CEO}$ compensation for full board approval (Daily et al., 1998; Ellig, 2003). Thus, our analysis examines the influence of compensation committees where the majority of members are non-executive directors. In order to do so, we hypothesize as follows:

Hypothesis 3: Having a non-executive-director-dominated compensation committee moderates the association between $\mathrm{CEO}$ pay and firm performance in such a way that the association is stronger where there is a non-executive dominated committee than where there is not.

\section{RESEARCH METHODS}

\section{Data and Sample}

The study draws on consecutive reported annual financial and compensation data collected on Australian public companies that were included in the S\&P/ASX 500 index (the share index representing the 500 most highly capitalized public companies traded on the Australian Securities Exchange) at any point in time between 1998-99 (the first year for which reliable Australian CEO compensation data are available) and 2005-06. The final sample includes 4456 company years of panel data covering a total of 663 distinct firms and 1257 individual CEOs. Company performance data were extracted chiefly from the e-databases FinAnalysis and DataStream, with additional transformations applied. All data were captured at balance date, with current dollar values inflation adjusted to 1999 real values using the Australian Consumer Price Inflation index. Foreign currency payments were also adjusted to Australia dollar values at the appropriate balance date. Turnover episodes were dummy-coded and controlled for in all regressions. Outgoing CEOs identified were coded 1, and 0 if otherwise. Incoming CEOs identified were coded 1 , and 0 if otherwise. Results remained qualitatively unchanged when turnover episodes were excluded.

\section{Measures}

CEO compensation measures. Our compensation measures focus on the cash component of CEO annual total compensation. In line with other studies (Daily et al., 1998; Makri et al., 2006) we use multiple measures of CEO cash compensation since this allows us to examine whether independent boards distinguish between performance incentive cash and fixed cash in the management of $\mathrm{CEO}$ performance incentives and risk bearing (Larraza-Kintana et al., 2007). Our study operationalizes three measures of CEO cash compensation. The first is a composite CEO Total Cash variable, encompassing both incentive and non-incentive cash components. Other studies utilizing a comparable compensation measure include Abowd (1990), Boyd (1994), Coughlan and Schmidt (1985), Decktop (1988), Levinthal (1988), and Merhebi et al. (2006). This measure 
includes salary, the reported monetary value of benefits, allowances, company superannuation contributions, and short-term cash incentives. The second compensation measure, CEO Annual Incentive Cash, is the level of reported annual performance-based cash compensation. The third measure, CEO Annual Non-Incentive Cash, includes all components of the total cash measure except the annual incentive cash component.

Although equity-based compensation has been instrumental in driving increases in CEO total compensation in Australia and elsewhere in recent times (Jensen et al., 2004; Shields, 2005), from a traditional Agency Theory perspective, CEO pay-for-firmperformance is a necessary requirement for managing information asymmetry and moral hazard irrespective of compensation mix and CEO-agent equity ownership (Aggarwal and Samwick, 1999; Jensen and Meckling, 1976). Consistent with this, a number of researchers suggest that it is reasonable to expect $\mathrm{CEO}$ cash compensation to co-vary with firm-level performance outcomes (Abowd, 1990; Jensen and Murphy, 1990; Makri et al., 2006). Thus, while it is necessary to recognize the growth in the relative importance of equity-based executive incentives, it is equally important to acknowledge that incentive plans that focus on short-term firm performance are primarily cash-based (Ellig, 2003). Further, compensation flowing from short-term cash incentive plans should, by definition, be more directly amenable to board determination and review than is compensation arising from long-term equity-based incentive plans. A study conducted by Makri et al. (2006) lends some credence to these suppositions in reporting that CEO annual incentive cash reward, rather than long-term equity-based incentives, were significantly related to firm-level performance. Further, Buck et al. (2003) find that the use of long-term incentive plans actually reduces the sensitivity of total reward to total shareholder return (TSR). Finally, we believe that a focus on CEO cash compensation does not limit the extent to which we are able to draw legitimate inferences regarding board independence and its relationship to CEO pay-for-firm-performance. As such, we contend that the exclusion of equity-based compensation is not a specification error of exclusion per se, as this does not affect the variance-covariance matrix, and thus does not bias estimates through omitted variable bias (Berry, 1993). ${ }^{[1]}$

Firm-level performance measure. Consistent with our earlier discussion of CEO outcomebased contracts, traditional Agency Theory predicts that boards in general will use specific firm-level performance outcome criteria to determine CEO compensation. Our decision to measure firm-level performance outcomes using firm market-returns is based on Agency Theory notions of CEO compensation as a principal-agent alignment mechanism, where the alignment of interests is induced by adjusting CEO pay to changes in shareholder returns (Jensen and Meckling, 1976). Research investigating the compensation-performance link in publicly listed companies has certainly shown a predilection for market-based or stock return performance metrics. In this study, consistent with the approach taken in many other studies (e.g. Abowd, 1990; Coughlan and Schmidt, 1985; Jensen and Murphy, 1990; Leone et al., 2005; Merhebi et al., 2006), we use annual real stock returns as the measure of firm market-returns. Real Returns are estimated as follows: $[(1+$ nominal return $) /(1+$ inflation rate $)]-1$.

Our preliminary modelling also investigated the possibility that boards may also use annual operating outcomes more directly attributable to $\mathrm{CEO}$ influence as criteria for 
determining $\mathrm{CEO}$ compensation, either additionally to market-returns or as an alternative to them. Consonant with this, a number of studies examining the sensitivity of CEO pay to firm-level performance outcomes have operationalized performance through accounting return measures (e.g. Conyon and Sadler, 2001; Izan et al., 1998; Jensen and Murphy, 1990; Ke et al., 1999; Leone et al., 2005; Lilling, 2006; Mishra et al., 2000; Raghavan et al., 2005). Accordingly, we conducted exploratory regression analyses using a number of accounting return measures reportedly used for compensation purposes, including return on invested capital (ROIG), return on assets (ROA), and return on equity (ROE) (Bender and Moir, 2006). In auxiliary analysis, the level of CEO annual incentive cash was regressed on these measures. However, contrary to Makri et al. (2006), who found that annual incentive cash reward was sensitive to accounting-return performance, in our exploratory modelling these non-market measures did not provide incremental explanatory power according to joint significance tests. Accordingly, our primary measures and modelling takes the traditional course of defining firm performance in market-based terms.

Board structural independence measures. In line with corporate governance best practice codes, extant research typically defines an 'independent' director as one who is not an executive employee of the firm, has no external business associations with the firm's GEO, and does not hold any external directorships in common with the CEO (Australian Stock Exchange Corporate Governance Council, 2003; Dalton et al., 1998, p. 276). Consistent with Managerial Power Theory, we suggest that non-executive (i.e. non-agent) status is the single most criterion valid demographic dimension of director independence. Further, in line with best practice codes, we examine specific aspects of board composition and structure where non-executive director presence is most commonly prescribed as a means of countervailing executive/agent self-interest. Accordingly, we use three measures of board independence: (i) having a non-executive director chairperson (a dichotomous measure of whether the chairperson was a nonexecutive director); (ii) the proportion (percentage) of non-executive directors on the board; and (iii) a non-executive director dominated compensation committee (a dichotomous measure of whether there was a formal compensation committee with a non-executive majority ${ }^{[2]}$.

Control variables. Consistent with Agency Theory perspectives, we have incorporated measures of firm size and market-return volatility as controls, with the latter serving as a proxy, for both employment risk and compensation risk.

It is well established that firm size continues to explain variance in $\mathrm{CEO}$ compensation above and beyond performance-based measures (Tosi et al., 2000). Again, firm size has been measured in various ways. In this study, firm size is measured as the natural logarithm of firm total assets (sourced from the FinAnalysis e-database) since it is less susceptible to collinearity with market-return accounting measure of firm performance than is the main alternative proxy for size, namely market capitalization.

In accordance with extant research, we expect that these risk factors will attenuate the association between CEO pay and firm-level performance (Aggarwal and Samwick, 1999; Larraza-Kintana et al., 2007; Miller et al., 2002; Mishra et al., 2000; Tosi et al., 
2000). As noted in the previous section, extraneous noise in share price performance can increase the CEO's risk bearing such that a risk compensation premium is required to offset the agent's risk aversion (Gomez-Mejia and Wiseman, 1997). Consequently, CEO pay-for-performance sensitivity is likely to fall as firm-specific risk increases. On this basis, it is appropriate to control for total firm risk as potentially influencing the extent to which CEOs are paid on the basis of firm performance. Thus, in line with the approach taken by Aggarwal and Samwick (1999), we have estimated firm risk, a total risk measure, as the cumulative distribution of the variance of firm monthly real returns, including dividends, over a minimum of three years (36 months) prior to the year $t$.

\section{Analyses and Model}

The standard approach to estimating the relationship between CEO pay and corporate governance structures has been to use OLS (ordinary least squares) with fixed effects. However, such an approach is highly problematic in the context of dynamic panel model estimation (Nickell, 1981). For these reasons, we have used a system GMM approach to estimation to account for the potential endogeneity problems associated with using a fixed effects approach to estimate a dynamic panel model. ${ }^{[3]}$ The system GMM was introduced by Arellano and Bond (1991, cited in Roodman, 2006) and further developed by Blundell and Bond (1998). The approach is capable of accounting for the potential for dynamic misspecification that has been overlooked in previous studies (Finkelstein and Hambrick, 1988) and the dynamism attendant to managing the relationship between CEO pay firm performance noted by Daily et al. (1998) and Wiseman and Gomez-Mejia (1998). It is also appropriate where $\mathcal{N}$ is large and $\mathcal{T}$ is moderate (Roodman, 2006). It is a more reliable approach to dynamic panel model estimation because it removes additional sources of contamination through an identified finite-sample corrected set of equations that are robust to panel-specific autocorrelation and heteroscedasticity (Roodman, 2006), and overcomes these problems by using both lagged differences and lagged levels to instrument dependent and independent variables. Purportedly endogenous and predetermined regressors (in this case, all explanatory variables excluding year dummies, turnover episodes, and firm risk) are differenced and instrumented using the differences and levels of exogenous regressors (Roodman, 2006).

Roodman (2006) recommends that two tests be conducted to ensure that instruments in the system GMM are valid and the moment conditions are adequate. The Hansen $\mathcal{f}$-test is conducted to test the validity of instruments, and the Arellano-Bond secondorder autocorrelation test - AR (2) - is conducted to ensure that there is no second-order serial correlation among residuals and that orthogonality has been achieved through the system (Roodman, 2006). The Hansen J statistic allows the testing of the null hypothesis that instruments are not correlated with the error term. The AR (2) statistic tests the null hypothesis that there is no second-order serial correlation in the disturbance term. Meeting both tests, as our instruments do, indicates that the system GMM is an appropriate model specification.

The following single equation encapsulates an identified multi-equation dynamic panel model of CEO compensation and performance relationship estimated through a system GMM approach: 


$$
C_{i, t}=\lambda_{1} \mathbf{E X}_{i, t}+\gamma_{i, t}+\lambda_{2} \mathbf{E W}_{i, t}+\left(V_{i}+\eta_{i, t}\right), i=1, \ldots, \mathcal{N} ; t=1, \ldots, \mathcal{T}
$$

where:

$C$ equals the dependent variable, which, in this case, is the natural logarithm of the relevant measure of $\mathrm{CEO}$ cash compensation.

EX is a vector for strictly exogenous variables. In the current study, these are year dummies, and turnover episodes. These variables are considered exogenous because there is little reason to suspect that they are predetermined or endogenous (Blundell and Bond, 1998; Roodman, 2006).

$\mathbf{E W}$ is the vector for predetermined or endogenous covariates. The $\mathbf{E W}$ vector includes explanatory variables including risk or the variance of firm market returns, board governance measures, firm size, and firm performance.

$V$ is the firm level fixed effects.

$\gamma$ is the external instrument vector for the performance variables.

$\eta$ is the error term that is assumed not to be auto-correlated, with the added assumption that $V$ and $\eta$ are not serially correlated.

\section{RESULTS}

In terms of the descriptive analysis, the annual means for the key explanatory variables were calculated to ascertain the extent to which the companies sampled demonstrated best practice board governance structures at the board and committee level, and, in particular, to establish whether there has been a linear trend in the adoption of these best practice principles. Table I presents the annual incidence of the three selected board governance measures for the full panel, with the final annual sample being between 424 and 560 firms, depending on the variable concerned.

In aggregate, the results show a steady increase in the preponderance of non-executive chairpersons and the percentage of non-executive directors, as well as the presence of

Table I. Annual means of board structural independence measures

\begin{tabular}{llll}
\hline \hline Year & $\begin{array}{l}\text { Non-executive } \\
\text { chair }\end{array}$ & $\begin{array}{l}\text { Proportion of } \\
\text { non-executive } \\
\text { directors on } \\
\text { board }\end{array}$ & $\begin{array}{l}\text { Non-executive } \\
\text { dominated } \\
\text { compensation } \\
\text { committee }\end{array}$ \\
\hline 1999 & & $66 \%$ & $54 \%$ \\
2000 & $73 \%$ & $67 \%$ & $59 \%$ \\
2001 & $73 \%$ & $67 \%$ & $61 \%$ \\
2002 & $75 \%$ & $68 \%$ & $64 \%$ \\
2003 & $76 \%$ & $69 \%$ & $67 \%$ \\
2004 & $78 \%$ & $69 \%$ & $72 \%$ \\
2005 & $77 \%$ & $70 \%$ & $76 \%$ \\
2006 & $71 \% \mathrm{a}$ & $71 \%$ & $78 \%$ \\
\hline \hline
\end{tabular}

Note: a Anomaly may be associated with corporate law reforms (CLERP 9) introduced in 2004. 
independent compensation committees. The results presented in Table I thus provide strong evidence of a secular trend towards the adoption of best practice corporate governance prescriptions. These results are consistent with those of Kiel and Nicholson (2003), who suggested that relative to the UK and the USA, Australia has shown a demonstrably greater adherence to prescriptions for board structural independence. The Australian trend towards a greater preponderance of non-executive chairpersons is somewhat divergent to research in the UK that suggests that CEO-duality is still a common practice in that context (see Reilly and Scott, 2005), as is also the case in the USA.

The Table I results also indicate that the general trend towards appointing nonexecutive directors predates the advent of a voluntary code favouring director independence in 2003 (Australian Stock Exchange Corporate Governance Council, 2003) and more stringent legislative requirements, especially following the enactment of the CLERP 9 legislation in 2004. Therefore, it appears that the trend towards non-executive presence may be attributable to mimetic and/or normative institutional pressures (DiMaggio and Powell, 1983) rather than to legislative compulsion.

Table II presents Pearson correlation coefficients for all model variables. According to the results, all three board independence measures are positively correlated $(r>0)$ with the level of CEO total cash compensation, the level of incentive cash compensation, and the level of non-incentive cash compensation both in year $t$ and year $t-1$.

However, three further facets of the Table II data are worthy of note. Firstly, and contrary to traditional Agency Theory logic, the data show no significant bivariate association between cash incentive payment levels and prior market returns. Secondly, there are significant negative correlations between firm risk, on the one hand, and (i) all board independence measures; and (ii) all cash compensation levels, on the other. This provides prima facie evidence, supportive of behavioural Agency Theory postulates, that insider-dominated boards may be a better fit in situations of high uncertainty. It also lends qualified support to the proposition that outcome-based incentives may be inappropriate in situations of high firm-level risk. Thirdly, the Table II results disclose consistent and positive associations between firm size, on the one hand, and all measures of board independence and cash compensation, on the other. Ceteris paribus, larger firms both pay more and have more independent board structures.

Non-executive directors. Table III presents the estimated coefficients relating to the moderating effects of the proportion of non-executive directors on the board on the relationship between the three measures of CEO cash compensation and real annual stock returns.

The proportion of non-executive directors on the board was predicted (Hypothesis 1) to have a positive effect on CEO pay-for-firm performance. According to the system GMM results, having a majority non-executive board has no significant association with any of the three CEO cash compensation measures. The estimated coefficients for the interactions between CEO annual incentive cash and non-incentive cash and firm real returns are near zero and non-significant.

Non-executive chairperson. Table IV presents the estimated coefficients testing the moderating effects of having a non-executive chairperson at the board level on the relationship between the three measures of $\mathrm{CEO}$ cash compensation and real annual stock returns. 
A. Capezio et al.

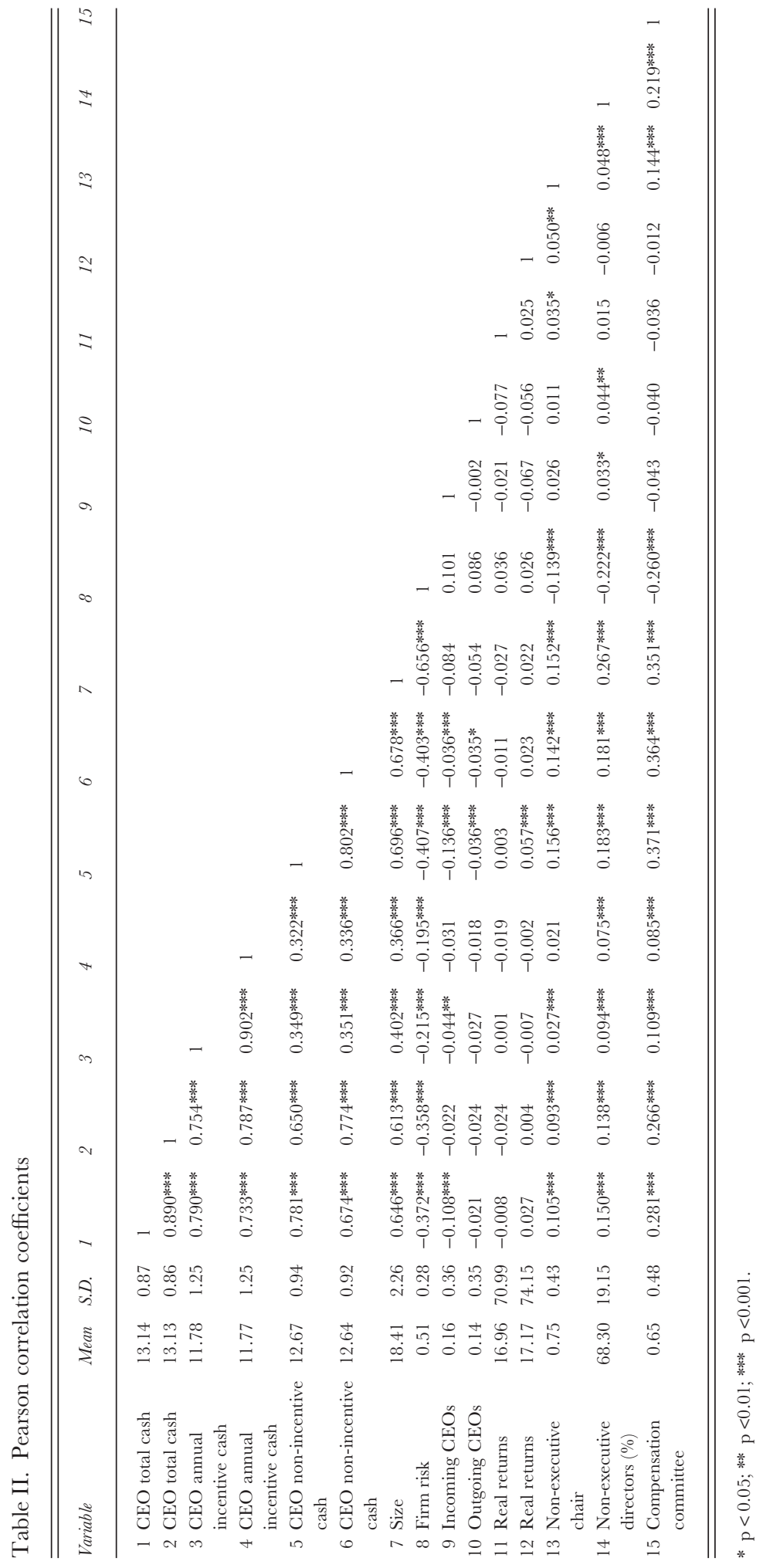


Table III. GMM estimated coefficients for non-executive directors, measures of CEO cash pay, and firm performance

\begin{tabular}{|c|c|c|c|}
\hline & $\begin{array}{l}\text { CEO total } \\
\text { cash }^{\mathrm{a}}\end{array}$ & $\begin{array}{l}\text { CEO annual } \\
\text { incentive cash }\end{array}$ & $\begin{array}{l}\text { CEO non- } \\
\text { incentive cash }\end{array}$ \\
\hline \multicolumn{4}{|l|}{ Board independence measure: } \\
\hline Non-executive directors ${ }^{b}$ & $\begin{array}{c}-0.001 \\
(0.001)\end{array}$ & $\begin{array}{l}0.000 \\
(0.001)\end{array}$ & $\begin{array}{c}0.000 \\
(0.001)\end{array}$ \\
\hline Non-executive directors $*$ real returns & $\begin{array}{c}0.000 \\
(0.001)\end{array}$ & $\begin{array}{c}0.000 \\
(0.001)\end{array}$ & $\begin{array}{l}0.000 \\
(0.001)\end{array}$ \\
\hline \multicolumn{4}{|l|}{ Controls: } \\
\hline Firm risk & $\begin{array}{c}-0.058 \\
(0.101)\end{array}$ & $\begin{array}{c}0.024 \\
(0.150)\end{array}$ & $\begin{array}{c}-0.041 \\
(0.128)\end{array}$ \\
\hline Size $^{\mathrm{a}}$ & $\begin{array}{l}0.046^{* * * *} \\
(0.020)\end{array}$ & $\begin{array}{l}0.032 \\
(0.023)\end{array}$ & $\begin{array}{l}0.107 * * * \\
(0.027)\end{array}$ \\
\hline Incoming $\mathrm{CEO}^{c}$ & $\begin{array}{l}-0.226 * * * \\
(0.026)\end{array}$ & $\begin{array}{c}-0.043 \\
(0.026)\end{array}$ & $\begin{array}{c}-0.285^{* * *} \\
(0.034)\end{array}$ \\
\hline Outgoing $\mathrm{CEO}^{c}$ & $\begin{array}{c}0.059^{*} \\
(0.029)\end{array}$ & $\begin{array}{c}-0.021 \\
(0.028)\end{array}$ & $\begin{array}{c}0.082^{*} \\
(0.038)\end{array}$ \\
\hline CEO total cash $^{\mathrm{a}}$ & $\begin{array}{l}0.862 * * * \\
(0.058)\end{array}$ & & \\
\hline CEO annual incentive cash $^{\mathrm{a}}$ & & $\begin{array}{l}0.856^{* * * *} \\
(0.044)\end{array}$ & \\
\hline CEO non-incentive cash $^{\mathrm{a}}$ & & & $\begin{array}{l}0.643 * * * \\
(0.079)\end{array}$ \\
\hline Real returns ${ }^{\mathrm{b}}$ & $\begin{array}{c}0.000 \\
(0.001)\end{array}$ & $\begin{array}{c}0.001 \\
(0.001)\end{array}$ & $\begin{array}{c}0.000 \\
(0.001)\end{array}$ \\
\hline Real returns ${ }^{\mathrm{b}}$ & $\begin{array}{c}0.000 \\
(0.001)\end{array}$ & $\begin{array}{c}-0.002 \\
(0.001)\end{array}$ & $\begin{array}{l}0.001 \\
(0.001)\end{array}$ \\
\hline Constant & $\begin{array}{c}1.12^{*} \\
(0.560)\end{array}$ & $\begin{array}{c}1.141^{*} \\
(0.530)\end{array}$ & $\begin{array}{l}2.662^{* * * *} \\
(0.731)\end{array}$ \\
\hline Observations & 2960 & 2960 & 2960 \\
\hline Hansen test of overidentification ( $\mathrm{p}$-value) & 0.103 & 0.104 & 0.136 \\
\hline AR 1 (p-value) & 0.000 & 0.002 & 0.000 \\
\hline AR 2 (p-value) & 0.076 & 0.130 & 0.162 \\
\hline
\end{tabular}

Notes:

${ }^{\text {a }}$ Natural logarithm.

${ }^{\mathrm{b}}$ Percentage.

${ }^{\mathrm{c}}$ Binary variable.

$* \mathrm{p}<0.05 ; * * \mathrm{p}<0.01 ; * * * \mathrm{p}<0.001$.

Robust standard errors in parentheses.

Hypothesis 2 predicted that having a non-executive chairperson on the board would positively moderate the relationship between CEO compensation and firm performance. The estimated coefficients in Table IV are inconsistent with this prediction. The presence of a non-executive chair does not positively moderate the relationship between annual real returns and any of the three measures of cash compensation. Thus, these results suggest that having a non-executive chairperson on the board does not enhance the association between CEO cash compensation and firm-level performance outcomes. 
Table IV. GMM estimates for non-executive chairpersons, measures of CEO cash pay, and firm performance

\begin{tabular}{|c|c|c|c|}
\hline & $\begin{array}{l}\text { CEO total } \\
\text { cash }^{\mathrm{a}}\end{array}$ & $\begin{array}{l}\text { CEO annual } \\
\text { incentive cash }\end{array}$ & $\begin{array}{l}\text { CEO non- } \\
\text { incentive cash }\end{array}$ \\
\hline \multicolumn{4}{|l|}{ Board independence measure: } \\
\hline Non-executive chair ${ }^{c}$ & $\begin{array}{c}0.029 \\
(0.028)\end{array}$ & $\begin{array}{c}0.031 \\
(0.037)\end{array}$ & $\begin{array}{c}0.100^{*} \\
(0.047)\end{array}$ \\
\hline Non-executive chair $*$ real returns & $\begin{array}{c}-0.001 \\
(0.001)\end{array}$ & $\begin{array}{c}0.000 \\
(0.000)\end{array}$ & $\begin{array}{c}0.000 \\
(0.000)\end{array}$ \\
\hline \multicolumn{4}{|l|}{ Controls: } \\
\hline Firm risk & $\begin{array}{r}-0.039 \\
(0.111)\end{array}$ & $\begin{array}{r}-0.035 \\
(0.119)\end{array}$ & $\begin{array}{c}0.219 \\
(0.150)\end{array}$ \\
\hline Size $^{a}$ & $\begin{array}{c}0.045^{*} \\
(0.020)\end{array}$ & $\begin{array}{c}0.032 \\
(0.017)\end{array}$ & $\begin{array}{l}0.187 \text { *** } \\
(0.021)\end{array}$ \\
\hline Incoming $\mathrm{CEO}^{c}$ & $\begin{array}{l}-0.228^{* * * *} \\
(0.027)\end{array}$ & $\begin{array}{c}-0.039 \\
(0.026)\end{array}$ & $\begin{array}{c}-0.224 * * * \\
(0.030)\end{array}$ \\
\hline Outgoing $\mathrm{CEO}^{\mathrm{c}}$ & $\begin{array}{c}0.049 \\
(0.028)\end{array}$ & $\begin{array}{c}-0.037 \\
(0.026)\end{array}$ & $\begin{array}{c}0.080 * \\
(0.039)\end{array}$ \\
\hline CEO total cash $^{\mathrm{a}}$ & $\begin{array}{l}0.846^{* * * *} \\
(0.058)\end{array}$ & & \\
\hline CEO annual incentive $\operatorname{cash}^{\mathrm{a}}$ & & $\begin{array}{l}0.867 * * * \\
(0.036)\end{array}$ & \\
\hline CEO non-incentive cash $^{\mathrm{a}}$ & & & $\begin{array}{l}0.369 * * * \\
(0.039)\end{array}$ \\
\hline Real returns ${ }^{\mathrm{b}}$ & $\begin{array}{c}0.001 \\
(0.001)\end{array}$ & $\begin{array}{c}0.000 \\
(0.001)\end{array}$ & $\begin{array}{l}0.000 \\
(0.000)\end{array}$ \\
\hline Real returns ${ }^{\mathrm{b}}$ & $\begin{array}{c}0.001 \\
(0.001)\end{array}$ & $\begin{array}{c}0.000 \\
(0.000)\end{array}$ & $\begin{array}{c}0.000 \\
(0.000)\end{array}$ \\
\hline Constant & $\begin{array}{l}1.228^{*} \\
(0.581)\end{array}$ & $\begin{array}{l}0.957^{*} \\
(0.475)\end{array}$ & $\begin{array}{l}4.415^{\text {**** }} \\
(0.567)\end{array}$ \\
\hline Observations & 2955 & 2955 & 2955 \\
\hline Hansen test of overidentification ( $\mathrm{p}$-value) & 0.358 & 0.352 & 0.126 \\
\hline AR 1 (p-value) & 0.000 & 0.000 & 0.000 \\
\hline AR 2 (p-value) & 0.176 & 0.132 & 0.753 \\
\hline
\end{tabular}

Notes:

${ }^{a}$ Natural logarithm.

${ }^{\mathrm{b}}$ Percentage.

${ }^{\mathrm{c}}$ Binary variable.

$* \mathrm{p}<0.05 ; * * \mathrm{p}<0.01 ; * * * \mathrm{p}<0.001$.

Robust standard errors in parentheses.

However, against expectations, the results also indicate that CEOs receive significantly higher levels of non-incentive cash when the chairperson in a non-executive. On the basis of these results, we reject Hypothesis 2.

Non-executive dominated compensation committees. Table V presents the estimated coefficients testing the moderating effects of having a non-executive director-dominated compensation committee on the relationship between the three measures of CEO cash compensation and real annual stock returns. 
The results provide no support for the proposition that having a formal independentdominated compensation committee enhances the association between CEO cash compensation and firm market performance outcomes. The estimated coefficients imply that CEOs in firms with such compensation committees do not receive significantly lower levels of CEO total cash, nor do they necessarily receive incentive cash compensation that is significantly more sensitive to lagged real stock returns. On the contrary, the Table $\mathrm{V}$ results show that CEOs in firms with such committees, on average, receive

Table V. GMM estimated coefficients for non-executive dominated compensation committees, measures of CEO cash pay, and firm performance

\begin{tabular}{|c|c|c|c|}
\hline & $\begin{array}{l}\text { CEO total } \\
\text { cash }^{\mathrm{a}}\end{array}$ & $\begin{array}{l}\text { CEO annual } \\
\text { incentive cash }\end{array}$ & $\begin{array}{l}\text { CEO non- } \\
\text { incentive cash }\end{array}$ \\
\hline \multicolumn{4}{|l|}{ Board independence measure: } \\
\hline Compensation committee ${ }^{c}$ & $\begin{array}{c}0.057 \\
(0.035)\end{array}$ & $\begin{array}{c}0.009 \\
(0.046)\end{array}$ & $\begin{array}{c}0.098^{*} \\
(0.042)\end{array}$ \\
\hline Compensation committee $*$ real return & $\begin{array}{c}-0.001 \\
(0.001)\end{array}$ & $\begin{array}{l}0.000 \\
(0.001)\end{array}$ & $\begin{array}{c}-0.001 \\
(0.001)\end{array}$ \\
\hline \multicolumn{4}{|l|}{ Controls: } \\
\hline Firm risk & $\begin{array}{r}-0.176 \\
(0.103)\end{array}$ & $\begin{array}{c}-0.223 \\
(0.155)\end{array}$ & $\begin{array}{c}-0.097 \\
(0.121)\end{array}$ \\
\hline Size $^{\mathrm{a}}$ & $\begin{array}{c}0.022^{*} \\
(0.019)\end{array}$ & $\begin{array}{c}0.010 \\
(0.023)\end{array}$ & $\begin{array}{l}0.095^{* *} \\
(0.030)\end{array}$ \\
\hline Incoming $\mathrm{CEO}^{\mathrm{c}}$ & $\begin{array}{c}-0.217^{* * *} \\
(0.028)\end{array}$ & $\begin{array}{c}-0.027 \\
(0.026)\end{array}$ & $\begin{array}{c}-0.250 * * * \\
(0.035)\end{array}$ \\
\hline Outgoing $\mathrm{CEO}^{c}$ & $\begin{array}{c}0.041 \\
(0.030)\end{array}$ & $\begin{array}{c}-0.020 \\
(0.027)\end{array}$ & $\begin{array}{c}0.060 \\
(0.038)\end{array}$ \\
\hline CEO total cash ${ }^{\mathrm{a}}$ & $\begin{array}{l}0.875^{* * * *} \\
(0.053)\end{array}$ & & \\
\hline GEO annual incentive cash ${ }^{\mathrm{a}}$ & & $\begin{array}{l}0.868 * * * \\
(0.044)\end{array}$ & \\
\hline CEO non-incentive cash $^{\mathrm{a}}$ & & & $\begin{array}{l}0.660^{* * * *} \\
(0.084)\end{array}$ \\
\hline Real returns ${ }^{\mathrm{b}}$ & $\begin{array}{l}0.000 \\
(0.001)\end{array}$ & $\begin{array}{l}0.000 \\
(0.001)\end{array}$ & $\begin{array}{c}0.000 \\
(0.001)\end{array}$ \\
\hline Real returns ${ }^{\mathrm{b}}$ & $\begin{array}{l}0.001 \\
(0.001)\end{array}$ & $\begin{array}{l}0.000 \\
(0.001)\end{array}$ & $\begin{array}{l}0.001 \\
(0.001)\end{array}$ \\
\hline Constant & $\begin{array}{l}1.321 * \\
(0.569)\end{array}$ & $\begin{array}{l}1.467^{* *} \\
(0.570)\end{array}$ & $\begin{array}{l}2.600^{* * * *} \\
(0.722)\end{array}$ \\
\hline Observations & 2958 & 2958 & 2958 \\
\hline Hansen test of overidentification ( $p$-value) & 0.595 & 0.417 & 0.229 \\
\hline AR 1 (p-value) & 0.000 & 0.009 & 0.000 \\
\hline AR 2 (p-value) & 0.253 & 0.169 & 0.151 \\
\hline
\end{tabular}

Notes:

a Natural logarithm.

b Percentage.

${ }^{c}$ Binary variable.

$* \mathrm{p}<0.05 ; * * \mathrm{p}<0.01 ; * * * \mathrm{p}<0.001$.

Robust standard errors in parentheses. 
significantly higher levels of total non-incentive cash compensation than do CEOs in firms without such committees. Accordingly, we reject Hypothesis 3.

The influence of firm size. Consistent with extant research we find positive and significant associations between CEO total cash and total non-incentive cash, on the one hand, and firm size, on the other. In line with extant research findings, this implies that CEOs receive higher levels of CEO total cash and non-incentive cash as firm size increases. However, there is no significant association between CEO incentive cash and firm size.

The influence of firm risk. The results in Table II showed consistent and significant negative bivariate associations between firm risk and cash reward levels. As noted previously, there is some evidence that firm-level risk may moderate board decisions regarding CEO pay mix in general and the ex ante use of outcome-based incentives in particular. However, the regression results presented in Tables III-V show no significant association between our multiple measures of $\mathrm{CEO}$ cash, including incentive cash, and total firm risk.

Outcome-based incentive plans and incentive alignment. Contrary to expectations, our results show no significant underlying association between payments levels received under cash incentive plans and annual real market returns. As noted above, auxiliary analysis with firm performance proxied using annual accounting measures (ROA and ROE) also produced non-significant coefficients. As such, our findings provide no support for the traditional Agency Theory postulate that the use of incentive plans necessarily enhances incentive alignment and CEO pay-for-performance sensitivity.

\section{DISGUSSION}

The most striking findings to emerge from this study are twofold. Firstly, contrary to traditional Agency Theory postulates, the use of CEO incentive cash payments is not associated with significantly stronger sensitivity of cash compensation to firm-level performance outcomes (whether proxied by real market returns or accounting returns). Secondly, contrary to the tenets of Managerial Power Theory, none of the three facets of board structural independence examined in this study significantly enhanced the association between CEO pay and firm performance. Indeed, against expectations, the only significant associations identified were those involving the level of non-incentive cash, on the one hand, and the presence of non-executive chairs and non-executive-dominated compensation committees, on the other. In both cases, the association was found to be positive. In short, contrary to Managerial Power Theory propositions, and after controlling for firm size and risk, executive chairs and executive-dominated compensation committees are likely to award lower rather than higher levels of fixed cash.

Despite examining the influence of multiple measures of board structural independence on multiple measures of $\mathrm{CEO}$ pay and firm performance, our results challenge the centrality of board structural arrangements as criterion-valid indicators of incentive alignment (inferred through CEO pay-for-firm-performance), board diligence in decision-making and, hence, good corporate governance. Our results are thus consistent 
with other studies that have found that having a preponderance of executives on the board may not lead to excessive or performance-decoupled CEO pay (Conyon, 2006; Conyon and Peck, 1998; Daily et al., 1998; Deutsch, 2005; Murphy, 2002). Likewise, a preponderance of independent/non-executive/outsider directors does not guarantee that $\mathrm{CEO}$ compensation will be coupled more strongly to firm performance outcomes.

These results are certainly inconsistent with studies that support Managerial Power postulates that 'weak' governance structures, such as CEO duality and executivedominated compensation committees, increase CEO pay levels and decouple CEO pay from firm performance (Core et al., 1999; Finkelstein and Hambrick, 1989). Our results show that non-executive-dominated boards actually pay CEOs significantly higher levels of non-incentive cash than do executive-dominated boards. This accords with Westphal's (1998) finding that 'good' governance practices reduce the level of performancecontingent pay whilst increasing the total level of CEO pay. Further, our findings are consistent with studies demonstrating that executive entrenchment at the full board and compensation committee level does not, of itself, contribute to the uncoupling of CEO pay from firm performance (Conyon, 2006; Dalton et al., 1998; Murphy, 2002). By the same token, however, our findings are not consistent with studies which suggest that having a larger proportion of knowledgeable insiders (i.e. executives) on the board necessarily serves to positively moderate, or increase, the performance sensitivity of CEO total cash (Core et al., 1999; Deutsch, 2005).

Our results thus suggest that boards dominated by independent/non-executive/ outsider directors are no more likely to either institute $\mathrm{CEO}$ pay-for-performance plans (through the process of ex ante performance incentives) or to subsequently enforce such plans (ex post pay-for-firm-performance). The overarching implication is that neither the instrumentalist logic of traditional Agency Theory nor the structural determinist logic of Managerial Power Theory are capable of explaining the association between prior and current firm-level performance outcomes, ex ante board decisions regarding $\mathrm{CEO}$ reward contracts, and observed ex post reward levels. Our findings indicate that there are problems with assuming that board structural characteristics, in the first instance, create the conditions for independent judgement and decision-making and, in the second instance, facilitate CEO pay-for-firm-performance. Given that firm size is the only consistent structural determinant of levels of CEO total cash and non-incentive cash pay, there would appear to be a need for a substantial reconsideration of the instrumentalism and determinism inherent in the dominant conceptual and prescriptive positions.

\section{Towards a Social-Cognitive Model of Board Behaviour and Agency}

Why, then, might it be that greater board and committee independence (indexed by a greater presence of non-executive directors) does not appear to be live up to expectations (at least with respect to the cash compensation of Australian CEOs)? Our contention here is that the structural emphasis on board independence stands to draw attention away from board decisional processes and capabilities in relation to $\mathrm{CEO}$ compensation and performance management. Structures are one thing; processes are quite another. Further, we suggest that behavioural Agency Theory may have explanatory salience 
here. As noted in the opening conceptual discussion, this approach recognizes that boards may use either behaviour-based or outcome-based criteria to measure and reward CEO performance, or a combination of the two (Eisenhardt, 1989; Makri et al., 2006; Wiseman and Gomez-Mejia, 1998). Moreover, it suggests that boards dominated by outsiders will be inclined to specify outcome-based incentives, not because they are necessarily more diligent (as both the traditional Agency Theory and Managerial Power approaches would suggest) but because non-executive outsiders are more susceptible to information asymmetry when it comes to evaluating CEO performance against behavioural criteria that are more validly and reliably attributable to the individual contributor (Wiseman and Gomez-Mejia, 1998). Further, while boards and committees dominated by non-executive outsiders may be more inclined to favour outcome-based incentive plans over direct behavioural monitoring, it does not necessarily follow that they will be more adept at configuring and enforcing outcome-based rewards.

More broadly, it is intuitive to propose that there are deeper social, institutional, cognitive, and behavioural processes in play that will influence ex ante and ex post CEO pay above and beyond board structural characteristics per se. A number of researchers have examined the role of social-cognitive and institutional processes in CEO pay determination (Bettis et al., 2005; Burns and Kedia, 2006; Cho and Hambrick, 2006; Devers et al., 2007; O'Reilly and Main, 2007; Westphal et al., 2006). In contrast to both traditional Agency Theory and Managerial Power perspectives, this literature suggests that outside non-executive directors are not necessarily more efficient monitors or decision-makers in the domain of CEO performance and reward management.

One long-espoused perspective is that CEO compensation is a function of board social ties that incline directors, regardless of whether they are external or internal appointees, to be more conciliatory towards the GEO (O'Reilly et al., 1988). Nonexecutive directors occupying executive positions in other firms may feel greater affinity with the incumbent CEO than with other stakeholders. Consistent with theories of class identity (Bilimoria, 1997), it is maintained that board social ties influence how outside directors manage and control CEO compensation, and can neutralize the independent monitoring and control of outside directors (Daily et al., 1998; O'Reilly and Main, 2007; Westphal and Zajac, 1997). As Westphal et al. (2006) note, along with these social ties come norms of reciprocity, trust, and resource interdependence which may result in board co-option.

There is evidence to support the social identity explanation. Perkins and Hendry (2005) found that nominally independent directors admitted that they were inclined to accept with minimal questioning the recommendations pertaining to executive rewards that were made by the top management team itself. Similarly, a study of 768 US company directors revealed that non-executive directors experienced acute role conflict in having to simultaneously serve the interests of shareholders while maintaining camaraderie on the board (Lawler and Finegold, 2007). The same directors reported that non-executive directors who were members of a remuneration committee felt compelled to appease the CEO. There is also mounting evidence that greater social diversity in the boardroom may enhance board strategic efficacy and, hence, firm performance (e.g. Miller and Triana, 2009). Our results offer at least circumstantial support for the proposition that the social cohesion of this largely self-selecting (and still predominantly 
older male) cohort continues to exercise greater sway over board compensation decisionmaking than any perceived distinction between independent and executive directors.

Relatedly, board decision-making can be theorized in terms of social comparative processes, social status, and institutional emulation (O'Reilly et al., 1988). Consistent with Institutional Theory (Barreto and Baden-Fuller, 2006; DiMaggio and Powell, 1983), it is plausible to suggest that boards may mimic the compensation practices of peer companies partly as a means to attracting and retaining scarce executive 'talent', but also as a means to enhancing their own social status and that of the firm. Externallyappointed non-executive directors may even be more prone to status concerns and mimicry than are their executive director counterparts. Westphal and Zajac (1997) demonstrated that outside directors made decisions about CEO pay on the basis of the CEO pay practices in their own firms.

These social and institutional processes may help explain why we find that size positively predicts CEO total cash, and non-incentive cash, but not incentive cash. Our results suggest that when it comes to size, boards may discriminate between fixed or non-incentive cash reward, and annual incentive cash reward. As firm size increases, so too does the level of CEO non-incentive cash. Further, our results indicate that board directors ratify CEO fixed compensation proposals on the basis of firm size, and not on the basis of total risk, or firm performance. This may well reflect differences in CEO 'job size', with boards legitimating fixed compensation in large firms on the basis of greater incumbent information demands and risk bearing. However, it is equally plausible to suggest that board decision-making here may be based more on considerations of social comparison and status than on any objective process of CEO job evaluation. Thus, reported CEO retention and attraction rationales for high fixed compensation in larger firms may serve to obscure fixed pay as a form of mimetic compensation which is reflective of norms of relative social status (O'Reilly et al., 1988; Zajac and Westphal, 1995) whereby CEOs can procure performance-decoupled compensation regardless of board structural composition.

As a way to rethink research, theory, and practice in this field, we see merit in integrating behavioural Agency Theory and social-cognitive and institutional perspectives on CEO pay determination within an information-processing or board decisionmaking model. For instance, under conditions where directors lack sufficient information to make efficacious and well considered appraisals of compensation proposals themselves, or to formulate such proposals, they may succumb to normative pressures stemming from social pressure to be conciliatory to the $\mathrm{CEO}$ and/or to preserve or enhance collective and company status. Viewed thus, CEO pay levels and pay-performance insensitivity may be best understood as an artefact of deep socio-normative and sociomimetic influences on board thinking, decision-making, and behaviour (Capezio and Shields, 2009).

\section{Limitations and Areas for Further Research}

Some may question whether these results are an artefact of the approach used to estimate parameters. To assess the reliability or our parameter estimates, and also to rule out the possibility that the absence of support for our hypotheses might have been methodologi- 
cally driven, we conducted AR (2) and Hansen $\mathcal{F}$-tests. For all model specifications, the p-values of the Hansen test for overidentification are non-significant, indicating that the instruments are valid in each model specification and are not correlated with the error term. The AR (1) p-values reported for each model specification are statistically significant. In rejecting the null hypothesis we provide evidence that the levels used to instrument the first-differenced equation provide weak instruments. The failure to reject the AR (2) test indicates that the errors in the system of equations are not serially correlated, and that orthogonality has been achieved. Following on from this, these results indicate that a system GMM, which uses both lagged levels and lagged differences for independent and dependent variables, is the appropriate approach to estimating parameters. The results reported indicate that the moment conditions are adequate and the instruments used are valid. Finding first-order autocorrelation in the error term further suggests that other single-equation approaches to parameter estimation may have biased estimates.

However, there are several caveats that should be acknowledged. Firstly, our compensation measures are limited to reported $\mathrm{CEO}$ annual cash payments. Yet, as we have argued, excluding the value of equity-based results does not bias the estimated parameters; it merely limits the extent to which inferences and generalizations can be made regarding CEO total reward and performance. Secondly, the performance criteria used focused on firm-level outcomes (indexed by real market returns), not CEO behaviour per se. This may not, however, amount to a misspecification in view of our focus on board independence. As behavioural Agency Theory suggests, since independent/nonexecutive/outsider boards may find it more difficult to appraise CEO behaviour on a regular basis, they will in any case be inclined to favour outcome-based rewards. Thirdly, the focus on shareholder returns may also be a limitation of this study, and may not adequately represent the totality of the CEO's performance and contribution. The board may use alternative outcome-based measures of firm performance to evaluate and reward $\mathrm{CEO}$ s, ranging from annual operating results to non-financial results relating to customer, employee, community, and other stakeholder interests. Environmental protection is also emerging as a significant performance criterion in executive reward in come countries (Berrone and Gomez-Mejia, 2009). Thus, given that our results are specific to a temporal and spatial context in which a shareholder-oriented model of corporate governance held sway, our findings may not be generalizable to other contexts in which different, broader stakeholder models and, hence, different notions of firm performance and, in turn, of reward alignment, may apply. We thus see merit in future research taking into consideration a broader range of performance criteria: outcomebased and behavioural; financial and non-financial; multi-stakeholder-based as well as shareholder-focused.

Our findings, and post hoc alternative conceptual approach, also have implications for future research methodology in this domain. The ubiquity of Agency Theory and Managerial Power Theory in extant empirical research may explain why very few studies interested in examining board influence over CEO pay have used methodologies attuned to behavioural and decisional process-orientated approaches. While we recognize the difficulties of examining decisional processes using multivariate regression analysis, we suggest that other estimation techniques, such as Partial Least Squares or Structural 
Equation Modelling with latent variables, do have considerable potential here. The use of survey techniques by behavioural agency theorists to examine CEO perceptions of board monitoring and CEO pay at risk (Caranikas-Walker et al., 2007; Tosi and GomezMejia, 1989) may also provide some direction for further exploring the social, cognitive, and information processing aspects of board decision-making. The application of qualitative methods, especially through case studies and in-depth interviewing, also promises to illuminate how non-executive and executive directors evaluate proposals put forward for the purpose of managing $\mathrm{CEO}$ incentive schemes, and $\mathrm{CEO}$ pay-for-performance. Only a limited number of studies have accorded due consideration to decision-making processes underpinning CEO pay through the use of in-depth interviewing (CaranikasWalker et al., 2007; Perkins and Hendry, 2005; Tosi and Gomez-Mejia, 1989). Interview method opens the way for a deeper understanding of the social dimensions of reward determination and to elucidate board perceptions of this decision-making process and the basis on which directors evaluate the efficacy of related proposals put forward for board approval.

\section{GONGLUSION}

Contrary to the tenets of corporate governance regulatory codes in Australia, the UK, the USA, and elsewhere, this study furnishes no support for the proposition that greater director independence (indexed by the presence of non-executive directors at the board chair, full board, and compensation committee level) positively moderates the relationship between lagged firm performance and CEO cash compensation level and composition. In terms of influencing CEO pay levels, we find that firm size matters greatly, whereas firm performance does not, and board structural independence influences only non-incentive cash - and in a way that contradicts Managerial Power predictions. Further, contrary to traditional Agency Theory postulates, we find that cash incentive payments do not serve, ex post, to strengthen incentive alignment.

It would appear from the results presented here that the principle and promise of both outcome-based incentive plans and board structural independence may, indeed, be too good to be true. At the very least, it is appropriate to suggest that, in relation to the role of the board in the principal-agent relationship, the tenets of 'good' board governance will only be verified when the practices prescribed can be proven to have enhanced the board's effectiveness in managing executive compensation levels, composition, and performance-sensitivity. Mimetic compliance with prescriptions for incentive use and director independence is one thing; negotiating the complex perceptual, cognitive, and affective processes associated with board determination of executive compensation is something else again; something that is arguably best understood and influenced by means of a socio-cognitive model of board outlook and decision-making. Such a focus, we suggest, may serve to move governance theory, research, and practice forward from the structural determinism that continues to characterize the domain.

\section{AGKNOWLEDGMENTS}

We wish to thank the Australian Research Council for assisting our research via an ARG Discovery Project grant during the triennium 2005-07. We are grateful for the constructive suggestions made by the anony- 
mous reviewers of this manuscript and by comments received on an earlier version of this study presented at the Academy of Management Annual Meeting held in Philadelphia in August 2007. We also wish to thank Kerry Jacobs for his helpful suggestions, as well as Colin Hales and the three anonymous reviewers for $\mathcal{F} M S$ for their constructive feedback and suggestions.

\section{NOTES}

[1] Australian researchers do face a significant challenge in not having access to reliable large sample time-series estimates of CEO total compensation before 2004. Until that year, it was not mandatory for Australian companies to report the estimated value of new equity based long-term incentive grants. Even after this time, the reporting of the values of equity based incentive plans is not methodologically consistent from company to company (Shields, 2005). However, our study by no means overlooks the importance of equity-related compensation, with CEO aggregate equity holdings being modelled as a lagged moderator of the cash compensation-performance relationship as part of preliminary analyses.

[2] Firms coded as having a 'formal independent committee' were those that identified the committee explicitly in the board member and committees tables. Firms were in addition coded 1 where 50 per cent or above were identified as non-executive directors.

[3] Using 2SLS (two stage least squares) and OLS approaches to parameter estimation is problematic because they do not eliminate dynamic panel bias arising from deeper lagged effects embedded in the error term (Roodman, 2006). Further, simulation studies suggest that OLS and 2SLS, in addition to first-differenced GMM, are biased by endogeneity and serial correlation, whereas the system GMM yields more reliable parameter estimates (Roodman, 2006). While the 2SLS estimator is useful in terms of ameliorating endogenous explanatory variables, it is still based on assumptions pertaining to a static linear model (Wooldridge, 2002), and in the specification of a dynamic panel model, estimates may still be susceptible to contamination from autoregressive processes and the weak instrument problem (Bun and Windmeijer, 2007). In addition, the two-step system GMM command in STATA allows specification of the depth of lags to account for dynamic misspecification which Finkelstein and Hambrick (1988) have highlighted as being a limitation of orthodox estimation practices. A further benefit of the system GMM approach in STATA is that through the 'robust' command, it is possible to ensure that the standard errors are robust to heteroscedasticity and arbitrary patterns of autocorrelations within firms (Roodman, 2006). Another benefit of this approach to estimation is that it preserves sample size. It uses forward orthogonal deviations - an alternative way to expunge the error term of fixed effects - and in so doing preserves the sample size (Baum et al., 2007; Roodman, 2006).

\section{REFERENGES}

Aboody, D. and Kasznik, R. (2000). 'CEO stock option awards and the timing of corporate voluntary disclosures'. Fournal of Accounting and Economics, 29, 73-100.

Abowd, J. M. (1990). 'Does performance-based managerial compensation affect corporate performance'. Industrial and Labor Relations Review, 43, 52-73.

Aggarwal, R. K. and Samwick, A. A. (1999). 'The other side of the trade-off: the impact of risk on executive compensation'. The Fournal of Political Economy, 107, 65-105.

Australian Stock Exchange Corporate Governance Council (2003). Principles of Good Corporate Governance and Best Practice Recommendations. Sydney: Australian Stock Exchange.

Barreto, I. and Baden-Fuller, C. (2006). 'To conform or to perform? Mimetic behaviour, legitimacy-based groups and performance consequences'. Fournal of Management Studies, 43, 1559-81.

Baum, C. F., Schaffer, M. E. and Stillman, S. (2007). 'Enhanced routines for IV/GMM estimation and testing'. The Stata Fournal, 7, 472-506.

Baysinger, B. D. and Hoskisson, R. E. (1990). 'The composition of the board of directors and strategic control: effects on corporate strategy'. Academy of Management Revierw, 15, 72-87.

Beatty, R. P. and Zajac, E. J. (1994). 'Managerial incentives, monitoring and risk bearing: a study of executive compensation, ownership, and board structure in initial public offerings'. Administrative Science Quarterly, 39, 313-35.

Bebchuk, L. and Fried, J. (2004). Pay Without Performance: The Unfulfilled Promise of Executive Compensation. Cambridge, MA: Harvard University Press. 
Bender, R. and Moir, L. (2006). 'Does "best practice" in setting executive pay in the UK encourage "good" behaviour?'. Fournal of Business Ethics, 67, 75-91.

Berrone, P. and Gomez-Mejia, L. R. (2009). 'Environmental performance and executive compensation: an integrated agency-institutional perspective'. Academy of Management Journal, 52, 103-26.

Berry, W. D. (1993). Understanding Regression Assumptions. Newbury Park, CA: Sage.

Bettis, J. C., Bizjak, J. M. and Lemmon, M. L. (2005). 'Exercise behaviour, valuation, and the incentive effects of employee stock options'. Fournal of Financial Economics, 76, 445-70.

Bilimoria, D. (1997). 'Perspectives on corporate control: implications for CEO compensation'. Human Relations, 50, 829-58.

Blundell, R. and Bond, S. (1998). 'Initial conditions and moment restrictions in dynamic panel data models'. Fournal of Econometrics, 87, 115-43.

Boyd, B. K. (1994). 'Board control and CEO compensation'. Strategic Management Fournal, 15, 335-44.

Buck, T., Bruce, A., Main, B. and Udueni, H. (2003). 'Long term incentives plans, executive pay and UK company performance'. Fournal of Management Studies, 40, 1709-27.

Bun, M. J. G. and Windmeijer, F. (2007). The Weak Instrument Problem of the System GMM Estimator in Dynamic Panel Data Models. Discussion Paper No. 07/595. Bristol: University of Bristol.

Burns, N. and Kedia, S. (2006). 'The impact of performance-based compensation on misreporting'. Fournal of Financial Economics, 79, 35-67.

Cadbury, A. (2002). Corporate Governance and Chairmanship. Oxford: Oxford University Press.

Capezio, A. and Shields, J. (2009). 'Sensitivity and sense-making: rethinking executive reward determination'. In Young, S. (Ed.), Contemporary Issues in International Corporate Governance. Melbourne, VIC: Tilde University Press.

Caranikas-Walker, F., Goel, S., Gomez-Mejia, L. R., Cardy, R. L. and Grabke-Rundell, A. (2007). 'An empirical investigation of the role of subjective performance assessments versus objective performance indicators as determinants of CEO compensation'. Management Research, 6, 7-26.

Cho, T. S. and Hambrick, D. C. (2006). 'Attention as the mediator between top management team characteristics and strategic change: the case of airline deregulation'. Organization Science, 17, 453-69.

Conyon, M. (2006). 'Executive compensation and incentives'. Academy of Management Perspectives, 20, 25-44.

Conyon, M. J. and Peck, S. I. (1998). 'Board control, compensation committees, and top down management compensation'. Academy of Management fournal, 41, 146-57.

Conyon, M. J. and Sadler, G. V. (2001). 'Executive pay, tournaments and corporate performance in UK firms'. International Fournal of Management Reviewes, 3, 141-68.

Core, J. E., Holthausen, R. W. and Larcker, D. F. (1999). 'Corporate governance, chief executive officer compensation, and firm performance'. Fournal of Financial Economics, 51, 371-406.

Coughlan, A. T. and Schmidt, R. M. (1985). 'Executive compensation, management turnover, and firm performance'. Fournal of Accounting and Economics, 7, 43-66.

Daily, G. M., Johnson, J. L., Ellstrand, A. E. and Dalton, D. R. (1998). 'Compensation committee composition as a determinant of CEO compensation'. Academy of Management Fournal, 41, 209-20.

Dalton, D. R. and Daily, C. M. (1994). 'Outside directors revisited: prescriptions for CEOs and directors'. Fournal of Small Business Strategy, 5, 57-68.

Dalton, D. R., Daily, C. M., Ellstrand, A. E. and Johnson, J. L. (1998). 'Meta-analytic review of board composition, leadership structure, and financial performance'. Strategic Management Fournal, 19, 269-90.

Decktop, J. R. (1988). 'Determinants of chief executive compensation'. Industrial and Labor Relations Review, 41, 215-26.

Deutsch, Y. (2005). 'The impact of board composition on firms' critical decisions: a meta-analytic review'. Journal of Management, 31, $424-44$.

Devers, C. E., Cannella, A. A., Reilly, G. P. and Yoder, M. E. (2007). 'Executive compensation: a multidisciplinary review of recent developments'. Fournal of Management, 33, 1016-72.

DiMaggio, P. J. and Powell, W. W. (1983). 'The iron case revisited: institutional isomorphism and collective rationality in organizational fields'. American Sociological Review, 48, 147-60.

Donaldson, L. and Davis, J. H. (1991). 'Stewardship theory or agency theory: CEO governance and shareholder returns'. Australian Fournal of Management, 16, 49-64.

Eisenhardt, K. L. (1989). 'Agency theory: an assessment and review'. Academy of Management Review, 14, $57-74$.

Ellig, B. R. (2003). The Complete Guide to Executive Compensation. New York: McGraw Hill.

Fama, E. F. (1980). 'Agency problems and the theory of the firm'. Fournal of Political Economy, 88, 288307. 
Fama, E. F. and Jensen, M. C. (1983). 'Separation of ownership and control'. Fournal of Law and Economics, 26, 301-25.

Finkelstein, S. and D'Aveni, R. A. (1994). 'CEO duality as a double-edged sword: how boards of directors balance entrenchment avoidance and unity of command'. Academy of Management Fournal, 37, $1079-108$.

Finkelstein, S. and Hambrick, D. (1988). 'Chief executive compensation: a synthesis and reconciliation'. Strategic Management Fournal, 9, 543-58.

Finkelstein, S. and Hambrick, D. (1989). 'Chief executive compensation: a study of the intersection of markets and political processes'. Strategic Management fournal, 10, 121-34.

Fong, E. A. (2010). 'Relative GEO underpayment and CEO behaviour towards R\&D spending'. Fournal of Management Studies, 47, 1095-122.

Gomez-Mejia, L. and Wiseman, R. M. (1997). 'Reframing executive compensation: an assessment and outlook'. Journal of Management, 23, 291-374.

Grabke-Rundell, A. and Gomez-Mejia, L. R. (2002). 'Power as a determinant of executive compensation'. Human Resource Management Review, 12, 3-23.

Gumbel, A. (2006). 'Managerial power and executive pay'. Oxford Fournal of Legal Studies, 26, 219-33.

Hall, B. J. and Liebman, J. B. (1998). 'Are CEOs really paid like bureaucrats?'. The Quarterly Journal of Economics, 113, 653-91.

Huse, M. (2007). Boards, Governance, and Value Creation. Cambridge: Cambridge University Press.

Izan, H. Y., Sidhu, B. and Taylor, S. (1998). 'Does CEO pay reflect performance? Some Australian evidence'. Corporate Governance: An International Review, 6, 39- 47.

Jensen, M. C. and Meckling, W. H. (1976). 'Theory of the firm: managerial behaviour, agency costs and ownership structure'. Fournal of Financial Economics, 3, 305-60.

Jensen, M. G. and Murphy, K. J. (1990). 'Performance pay and top-management incentives'. Fournal of Political Economy, 98, 225-64.

Jensen, M. C., Murphy, K. J. and Wruck, E. (2004). Remuneration: Where We've Been, How We Got Here, What Are the Problems, and How to Fix Them. Finance Working Paper No. 44(2004). Brussels: European Corporate Governance Institute.

Ke, B., Petroni, K. and Safieddine, A. (1999). 'Ownership concentration and the sensitivity of executive pay to accounting performance measures: evidence from publicly and privately held insurance companies'. Fournal of Accounting and Economics, 28, 185-209.

Kerr, J. L. and Kren, L. (1992). 'Effect of relative decision monitoring on chief executive compensation'. Academy of Management, 35, 370-97.

Kiel, G. G. and Nicholson, G. J. (2003). 'Board composition and corporate performance: how the Australian experience informs contrasting theories of corporate governance'. Corporate Governance, 11, 189-205.

Knopf, J. D., Nam, J. and Thornton, J. H. (2002). 'The volatility and price sensitivities of managerial stock option portfolios and corporate hedging'. Fournal of Finance, 57, 801-13.

Lambert, R. A. and Larcker, D. F. (1987). 'An analysis of the use of accounting and market measures of performance in executive compensation contracts'. Fournal of Accounting Research, 25, 85-125.

Larraza-Kintana, M., Wiseman, R. M., Gomez-Mejia, L. R. and Welbourne, T. M. (2007). 'Disentangling compensation and employment risks using the behavioural agency theory model'. Strategic Management Journal, 28, 1001-19.

Lawler, E. and Finegold, D. (2007). 'CEO compensation: what board members think'. WorldatWork Fournal, 16, $38-47$.

Leone, A. J., Wu, J. S. and Zimmerman, J. L. (2005). 'Asymmetric sensitivity of CEO cash compensation to stock returns'. Fournal of Accounting and Economics, 42, 167-92.

Levinthal, D. (1988). 'A survey of agency models of organisations'. Fournal of Economic Behavior and Organization, 9, 153-85.

Lilling, M. S. (2006). 'The link between CEO compensation and firm performance: does simultaneity matter?'. Atlantic Economic Fournal, 34, 101-14.

Makri, M., Lane, P. J. and Gomez-Mejia, L. R. (2006). 'CEO incentives, innovation, and performance in technology-intensive firms: a reconciliation of outcome and behavior-based incentive schemes'. Strategic Management fournal, 27, 1057-80.

Merhebi, R., Pattenden, K., Swan, P. L. and Zhou, X. (2006). 'Australian chief executive officer compensation: pay and performance'. Accounting and Finance, 46, 481-97.

Miller, T. and Triana, M. (2009). 'Demographic diversity in the boardroom: mediators of the board diversity-firm performance relationship'. Fournal of Management Studies, 46, 755-86. 
Miller, J. S., Wiseman, R. M. and Gomez-Mejia, L. R. (2002). 'The fit between CEO compensation design and firm risk'. Academy of Management Journal, 45, 745-56.

Mishra, C. S., McConaughy, D. L. and Gobeli, D. H. (2000). 'Effectiveness of CEO pay-for-performance'. Review of Financial Economics, 9, 1-13.

Murphy, K. J. (2002). 'Explaining executive compensation: managerial power versus the perceived cost of stock options'. The University of Chicago Law Review, 69, 847-69.

Nickell, S. (1981). 'Biases in dynamic models with fixed effects'. Econometrica, 49, 1417-26.

O'Reilly, G. A. and Main, B. G. M. (2007). 'It's more than simple economics'. Organizational Dynamics, 36, $1-12$.

O’Reilly, G. A., Main, B. G. M. and Crystal, G. S. (1988). 'GEO compensation as tournament and social comparison: a tale of two theories'. Administrative Science Quarterly, 33, 257-74.

Perkins, S. J. and Hendry, C. (2005). 'Ordering top pay: interpreting the signals'. Fournal of Management Studies, 42, 222-38.

Pfeffer, J. (1972). 'Size and composition of corporate boards of directors: the organization and its environment'. Administrative Science Quarterly, 17, 221-8.

Raghavan, R., Iyengar, J., Williams, J. H. and Zampelli, E. M. (2005). 'Sensitivity of executive pay to accounting performance measures in all equity firms'. Accounting and Finance, 45, 577-95.

Reilly, M. and Scott, D. (2005). 'An inside look at the compensation committee'. WorldatWork fournal, 42, $34-40$.

Roodman, D. (2006). How To Do xtabond2: An Introduction to 'Difference' and 'System' GMM in STATA. Working Paper No. 103. Washington, DC: Center for Global Development.

Shields, J. L. (2005). 'Setting the double standard: chief executive pay the BCA way'. Fournal of Australian Political Economy, 56, 299-324.

Sundaramurthy, C. and Lewis, M. (2003). 'Controls and collaboration: paradoxes of governance'. Academy of Management Review, 28, 397-415.

Tosi, H. L. and Gomez-Mejia, L. R. (1989). 'The decoupling of CEO pay and performance: an agency theory perspective'. Administrative Science Quarterly, 34, 169-89.

Tosi, H. L., Werner, S., Katz, J. and Gomez-Mejia, L. R. (2000). 'How much does performance matter? A meta-analysis of executive compensation studies'. Foumal of Management, 26, 301-39.

Westphal, J. D. (1998). 'Collaboration in the boardroom: behavioral and performance consequences of CEO-board social ties'. Academy of Management Fournal, 42, 7-24.

Westphal, J. D. and Zajac, E. J. (1997). 'Defections from the inner circle: social exchange, reciprocity, and the diffusion of board independence in U.S corporations'. Administrative Science Quarterly, 42, 161-83.

Westphal, J. D., Boivie, S. and Chung, D. H. (2006). 'The strategic impetus for social network ties: reconstituting broken CEO friendship ties'. Strategic Management Fournal, 27, 425-45.

Wiseman, R. M. and Gomez-Mejia, L. R. (1998). 'A behavioural agency theory model of managerial risk taking'. Academy of Management Review, 23, 133-53.

Wooldridge, J. M. (2002). Econometric Analysis of Cross Section and Panel Data. Cambridge, MA: MIT Press.

Zajac, E. J. and Westphal, J. D. (1995). 'Accounting for the explanations of CEO compensations: substance and symbolism’. Administrative Science Quarterly, 40, 283-308.

\section{Legislation Gited}

Corporate Law Economic Reform Program (Audit Reform and Corporate Disclosure) 2004 [CLERP 9]

Corporations Act 2001

Company Law Review Act 1998 